Peer-reviewed article

(C) Journal of International Students

Volume 10, Issue 1 (2020), pp. 181-202

ISSN: 2162-3104 (Print), 2166-3750 (Online)

Doi: $10.32674 /$ jis.v10i1.1049

ojed.org/jis

\title{
Exploring East Asian Undergraduate Students' Perceptions about the Effectiveness of their Preparation for Study Abroad for Academic Success in U.S. Universities
}

\author{
Meiren Chen \\ Hyeyoung Bang \\ Bowling Green State University, USA
}

\begin{abstract}
In this study we used grounded theory framework to explore how preparation for studying abroad affects the academic success of East Asian undergraduate students in U.S. universities. Based on interviews with 12 participants from China, Hong Kong, South Korea, and Taiwan, we found that knowledge of English language and American culture, which is closely involved with their preparation for study abroad and their undergraduate study in the United States, are two core categories affecting East Asian students' academic success. High levels of preparation for study abroad help East Asian students better adapt to American universities. At the same time, East Asian students spend more time on English proficiency tests than learning the culture both before and after they arrive to the United States, which can be detrimental. We suggest that U.S. universities provide more support for cultural adaptation such as learning communities to have active cultural exchanges within context.
\end{abstract}

Keywords: academic success, American universities, East Asian undergraduate students, grounded theory, study abroad preparation 


\section{INTRODUCTION}

Universities in the United States attract thousands of East Asian students each year. As preparation for studying in American universities, many East Asian students study in international high schools, English language schools, international exchange programs, and other programs related to study abroad (College Board, 2014; J. K. Park, 2009). When they start their studies in the United States, however, they still face various challenges in both life and academics due to significant differences in language, schooling, and values (Choi \& Nieminen, 2013). There is a plethora of research investigating the challenges international students face in American universities (e.g., Ra \& Trusty 2017; Wu, Garza, \& Guzman, 2015; Yan \& Berliner, 2013). However, less research explores the students' study abroad preparation experiences before they come to American universities, and the connection between these experiences and the students' academic success (Salyers et al., 2015). Thus, this study explores East Asian students' education experiences and preparation for studying abroad experiences, and how their challenges in U.S. higher education institutions influence their perception of academic success in American universities. The study may help U.S. universities understand how East Asian students prepare to study in the United States, and what support the students may need on U.S. university campuses.

\section{LITERATURE REVIEW}

\section{East Asian Students in the United States}

The United States is one of the most popular study abroad destinations and attracts thousands of international students pursuing U.S. diplomas (UNESCO Institute for Statistics, 2019). The Open Doors Report (Institute of International Education [IIE], 2019) indicates that in 2018-2019, the number of international students in the United States rose to $1,094,792$, which is a $1.5 \%$ growth from the previous year. From the perspective of places of origin, East Asian international students have become the largest group of all international students in the past decade. East Asia includes China, Hong Kong, Japan, Mongolia, North Korea, South Korea, and Taiwan. According to IIE (2019) the number of East Asian students in the United States has grown from 189,371 in 2000-2001 to 468,304 in 2018-2019. In 20182019 , the population accounted for more than $42.8 \%$ of all international students. In the top 25 places of origin, China's increase of $3.6 \%$ from previous year ranked first $(33.2 \%)$. Although negative growth has been seen in the number of students from South Korea and Japan in recent years, the two countries still respectively ranked in the third and eighth in the top 25 , while Taiwan, at $4.4 \%$, increased its ranked to seventh place in 2018/19. 


\section{Background: Reasons for Studying in the United States}

\section{The Push-Pull Model, and Preference for American Universities}

There are many factors that affect international students' decisions to study abroad and their particular destination choices. The push-pull model has prevalently been used as a framework in previous research to explain international students' decisions on their study abroad destinations (Gong \& Huybers, 2015; JamesMacEachern \& Yun, 2017; Mazzarol \& Soutar, 2002). Mazzarol and Soutar (2002), for instance, conducted three surveys among students from four Asian countries to examine the factors that affected students' choice of a host country. They discovered both push factors, such as the lack of educational opportunities, parent, family, and friend influence, and knowledge about the host countries, and pull factors, such as the educational quality, reputation, cost, and environment of the host countries, might affect students' choice on their study abroad destinations. They found that students were more likely to choose the countries that had better overall reputations (in terms of higher education institutions and life generally) in their home countries. This particular finding helps explain why the United States has become a popular host country for international students. Mazzarol and Soutar also indicated that U.S. influence on news, film, television, and other media in the world since the 1950s has built overall positive reputations of the country, which has helped increase students' desire to study in the United States.

According to UNESCO's Institute of Statistics (2019), the United States is the most popular study abroad destination for students in China, South Korea, and Japan. An essential factor that has affected East Asian students' choice to study in the United States is that attaining high test scores and going to elite universities are highly valued experiences in Asian societies and cultures (M. Lee et al., 2013). The Academic Ranking of World Universities (2018) also showed that the United States has 139 of the Top 500 universities in the world, the largest number of any country, and almost 4 times (3.6 times) as many as those in the United Kingdom (39 universities).

\section{Schooling and Education in East Asia}

\section{Value of Education and High Expectations of Academic Success}

Confucian culture is the core to understanding East Asian education, and it laid the foundation for the traditional pedagogies and educational values across East Asia (Starr, 2012). The key concepts of education in Confucian principles highlight the importance of educating the young, and gaining competence through practice and hard work. This ethic is still followed in modern East Asian countries and has played an important role for valuing education (T. Kim, 2009). Another historical influence is the keju, the imperial examination that was introduced in the Sui Dynasty in China in the seventh century that played an important role in selecting scholars and officials. Later, it was introduced to Japan in 701 CE and Korea in 958 CE. Keju in China lasted until 1905 when the Qing government abolished the system (Suen \& Yu, 2006). For many individuals, this testing system was the only selective passage to become 
governmental workers, which was considered greatly honorable and brought the eminence to the family. Although this ancient selection system was abolished, a national examination is still usually used as the sole criterion for different types of selection, especially in college admissions (Choi \& Nieminen, 2013).

Similarly, in many modern East Asian countries, higher academic degrees, especially degrees that lead to desired jobs, have been highly valued (Choi \& Nieminen, 2013; Mitsui, 2009). For instance, Korean students believe that students who have studied at prestigious Korean universities or foreign universities will have more and better opportunities in job hunting (Mitsui, 2009). Since the college entrance examinations are taken annually, students in South Korea who fail to enter their universities of choice might attend cram schools for another year to retake the examinations (Nuffic, 2013; Kwon, Lee, \& Shin, 2017). Muthanna and Sang (2015) reported that Chinese students in the above situation might repeat their last year of high school. Fong (2007) explained that Chinese students receive more care and concern from their parents than those with siblings due to the one-child policy, which shoulders more responsibilities for Chinese singletons to go to elite universities to support their families. As the only hope in the family, they are supposed to be successful in both academics and their career in order to support and honor their families in the future (Fong, 2007).

\section{Primary and Secondary Education in China, Hong Kong, South Korea, and Taiwan}

The school setting, teaching styles, and students' learning styles in primary and secondary schools in China, Hong Kong, South Korea, and Taiwan are highly similar. Previous studies have described that class instructions in East Asia are very structured and test-oriented, which leads students to become passive learners (Chan, 2014; Flaitz, 2003). According to Flaitz (2003), in East Asia, students seldom actively engage in knowledge construction and practice together, usually passively memorizing the teachers' instructions, and using memorization as a main strategy when preparing for exams. Examinations are also an essential part of East Asian education systems. Choi and Nieminen (2013) described that for East Asian students, their main goal in school is to gain high scores on the exams and receive admissions to elite universities, which they believe will provide better career opportunities in the future (Mitsui, 2009). Finally, in these country contexts, academic achievement, particularly getting high exam scores, involves a lot of extra effort after school (Chou \& Ho, 2007; Flaitz, 2003; Nuffic, 2013; Kwon, Lee, \& Shin, 2017). Although some of these studies might be dated, it is still common nowadays that students in East Asia exert great efforts on their studies in and after school.

\section{English Education in the Four Countries}

In China, South Korea, Taiwan, and Hong Kong, English is a required subject beginning in primary school and also one of the required subjects in college entrance exams (Chou \& Ho, 2007; Wang, 2007). Pan and Block (2011) as well as J. S. Park (2011) found that East Asians want to learn English because they believe that 
mastering the language will help them find better jobs. At the same time, many companies and organizations require their applicants to have high scores on English proficiency tests such as TOEIC (Test of English for International Communication) and TOEFL (Test of English as a Foreign Language). However, the curricula of English education in primary and secondary school rely a lot on grammar, reading, and tests. For instance, Chou and Ho (2007) reported that the goal for many Taiwanese students who attend private language schools is to improve their skills in taking English exams, instead of improving their English communication skills.

\section{Preparation for Studying in American Universities}

According to IIE (2019), the number of East Asian students in American universities is much larger than the number of East Asian students in American high schools, which strongly suggests that most East Asian undergraduate students in American universities did not attend high schools in the United States and will face both academic and social challenges as newcomers such as the language barriers, college admission requirements, different pedagogies, and acculturation issues.

\section{Test Preparation Programs}

Admission offices in American universities often ask international students to submit Test of English as a Foreign Language (TOEFL) or the International English Language Testing System (IELTS) scores, and some offices ask for Scholastic Assessment Test (SAT) or American College Testing (ACT) scores as well. Although many studies have found that test preparation programs do not significantly affect students' performance in TOEFL, IELTS, or SAT tests (Liu, 2014; Powers \& Rock, 1999), many East Asian students still attend these programs. In China, the most wellknown language school, the New Oriental (xin dong fang), which provides various English training programs, had 8.4 million students enrolled in fiscal year 2019 (New Oriental Education \& Technology Group, n.d.). Roberts (2002) reported that Koreans prefer to attend coaching programs for TOEFL preparation, because they believe that taking preparation courses might dramatically improve their test results.

\section{International High School Programs}

Many high schools in East Asia now offer Advanced Placement (AP) courses, A-Level courses, International Baccalaureate Diploma Programmes (IBDP), etc. In 2010, the College Board established a cooperative relationship with the Ministry of Education of the People's Republic of China to introduce AP courses to Chinese high schools (Xie, 2011). The standard examinations for college admission in Hong Kong were designed based on A-Level models (Hong Kong Education Bureau, 2020). By June 2018, there were 102 schools in China, 29 schools in Hong Kong, 11 schools in South Korea, 38 schools in Japan, and eight schools in Taiwan offering IBDP (International Baccalaureate, n.d.). 


\section{Bridge Programs and English as Second Language Programs}

Bridge programs and English as a second language (ESL) programs provide more options for international students to improve their English and prepare for their undergraduate studies in U.S. universities. For example, the University of San Francisco offers a summer bridge program to Chinese students. This program not only provides academic English courses but also helps students adapt to American culture and get involved with the local community (Bergenfeld, 2011).

\section{Agency Help in the Application Process}

American universities require application forms, standardized test scores, English proficiency test scores, high school transcripts, recommendation letters, personal statements, and other documents, while most East Asian universities admit students mainly based on the scores of college entrance exams. Due to the different university application procedures, agency help is commonly used by the applicants from East Asian countries. These study abroad agencies help students select schools that fit their academic goals and help them prepare application materials, and they charge students high service fees for doing so.

In China, some agencies even require students who receive admissions from topranking schools to pay a bonus (Winn, 2012). According to Hagedorn and Zhang (2011), 69\% of the Chinese participants reported that they used or would use agency services to apply to undergraduate programs in the United States. They found that students chose agency help because of their lack of knowledge in the application process, visa application methods, and general information about foreign institutions. Some students believed that choosing an agency improved their chances of being admitted. However, those students who did not use agency help believed that they had time and ability to complete university applications on their own, and they also expressed mistrust in the agencies, and that the expense for the service was too high (Hagedorn \& Zhang, 2011).

\section{Research Questions}

The purpose of this study was to find how the preparation for study abroad that East Asian international students made would affect their academic success in American universities. Many factors, such as English proficiency, social economic status, and academic performance in high school are commonly used to examine international students' academic success in college (Ra \& Trusty 2017; Wu et al., 2015; Yan \& Berliner, 2013). However, few studies have investigated the relationship between international student's pre-departure preparation and their academic success in American universities. We found that grounded theory in particular pertained well to this research, as explained further below. The research questions in this study are as follows:

1. How did East Asian students prepare to study in American universities? 
2. How did their preparation affect their academic success in American universities?

3. What challenges do they face after the initial arrival?

\section{METHODS}

\section{Participants}

After obtaining Human Subject Review Board approval for the research, we used a convenience sampling method to recruit participants. The criteria for the participants were that they be current undergraduate students in American universities who were from East Asian countries, and over 18 years old. In the process of recruiting our participants, we first posted recruiting information on the weekly "campus update" at a university in the midwestern region. Simultaneously, we used the snow-ball technique by sending recruitment emails to the international East Asian students we knew as well as the supervisors of East Asian clubs, asking them to forward the information to their East Asian friends. Twelve eligible participants responded to voluntarily participate in this study. We recruited participants who are from different part of East Asian countries. We also attempted equal sex distribution. However, we were unable to recruit participants from Japan, Mongolia, and North Korea because they are less populated in the five universities where we collected the data. Likewise, we do have more Chinese students because Chinese students represent the highest number of international students in U.S. universities.

Twelve participants, six males and six females, participated in this study. The participants, whose ages ranged was from 19 to 27, were all from East Asian countries (seven from Mainland China, three from South Korea, one from Hong Kong, and one from Taiwan). They studied in two public universities on the West Coast, two public universities in the Midwest, and one private university in the Midwest (See Table 1).

Table 1: Demographic Information

\begin{tabular}{|c|c|c|c|c|c|c|c|c|c|c|}
\hline Name & Age & Sex & Ethnicity & $\begin{array}{c}\text { Native } \\
\text { language }\end{array}$ & $\begin{array}{l}\text { Year of HS } \\
\text { graduation }\end{array}$ & $\begin{array}{l}\text { Year } \\
\text { came to } \\
\text { USA }\end{array}$ & $\begin{array}{l}\text { Current } \\
\text { year of } \\
\text { school }\end{array}$ & Major & $\begin{array}{l}\text { English } \\
\text { proficiency } \\
\text { test time }\end{array}$ & $\begin{array}{c}\text { English } \\
\text { Proficiency } \\
\text { (TOEFL iBT/ } \\
\text { IELTS) Scores* }\end{array}$ \\
\hline Xa-wen & 20 & $\mathrm{~F}$ & Taiwan & Mandarin & 2012 & 2012 & Junior & Com & 2012 & unknown \\
\hline Nana & 19 & $\mathrm{~F}$ & China & Mandarin & 2013 & 2013 & Sophomore & Arch & 2012 & TOEFL 101-120 \\
\hline Shichao & 23 & M & China & Mandarin & 2010 & 2010 & Senior & Busi & I & I \\
\hline Kai & 24 & M & China & Mandarin & 2009 & 2010 & Senior & Com & 2010 & TOEFL $<60$ \\
\hline Mengchen & 19 & $\mathrm{~F}$ & China & Mandarin & 2013 & 2013 & Sophomore & Bio & 2012 & TOEFL 101-120 \\
\hline Fang & 20 & $\mathrm{~F}$ & China & Mandarin & 2012 & 2014 & Junior & Eng & 2013 & unknown \\
\hline Pengfei & 21 & M & China & Mandarin & 2012 & 2013 & First year & Comm & I & I \\
\hline Sung-min & 25 & M & S. Korea & Korean & 2008 & 2014 & First year & Busi & 2013 & TOEFL 79-100 \\
\hline Chin-wah & 21 & $\mathrm{~F}$ & $\begin{array}{l}\text { Hong } \\
\text { Kong }\end{array}$ & Cantonese & 2012 & 2014 & Senior & Accou & 2012 & IELTS 6.5-7.0 \\
\hline Dohyyun & 27 & M & S. Korea & Korean & 2006 & 2010 & Senior & SpoMa & I & 1 \\
\hline Joowon & 22 & $\mathrm{M}$ & S. Korea & Korean & 2011 & 2011 & Junior & Busi & 2010 & TOEFL 101-120 \\
\hline Shanshan & 21 & $\mathrm{~F}$ & China & Mandarin & 2011 & 2014 & Senior & Econ & 2014 & TOEFL $61-78$ \\
\hline
\end{tabular}


Note. Pseudonyms were used to protect the participants' identity and presented in alphabetical. TOEFLiBT $=$ Test of English as a Foreign Language, Internet-based Test, IELTS = International English Language Testing System, Com = Computer Science, Arch $=$ Architecture, Busi $=$ Business, Bio $=$ Biology, Eng $=$ English, Comm $=$ Communication, Accou $=$ Accounting, SpoMa $=$ Sport Management, Econ $=$ Economics.

Each participant completed a demographic form and participated in a semi structured individual audio recorded interview. The demographic form was designed to collect the basic descriptive information of participants. Each participant was identified by a pseudonym. Table 1 provides the demographic information of the participants. During the semi-structured individual interviews, both closed-ended and open-ended questions were asked and audiorecorded. Interview questions are listed in the Appendix A.

\section{Methodology and Analysis}

Grounded theory develops theories of social phenomena through categories formulated in the process of data analysis (Ritchie \& Lewis, 2003). The phenomenon researched in this study was the preparation of East Asian prior to their acceptance to universities in the United States. It was unknown if their preparation would make their academic life in college any different. Thus, this study used grounded theory under a qualitative approach to explore participants' answers.

In grounded theory, the coding process includes three steps: open coding, axial coding, and selective coding. It is iteratively conducted to increase the reliability of the analysis (Berg \& Lune, 2004). All data in this study were coded by following the three steps in an iterative manner. The data of each interview were separately coded in the data collection process, and memos were taken during this process. After the completion of the interviews, data were coded again to increase the reliability of the results. In the process of theoretical analysis, data were repeatedly coded and categorized, and were constantly compared to develop the theory.

We labeled 298 units and used the units to generate 38 concepts during opening coding. We generated four themes and 10 subthemes from the axial coding process. In the selective coding process, the core category, knowledge of English language and American culture, was integrated based on the analysis of the four themes and 10 subthemes.

\section{RESULTS}

The findings of this study identify four themes and 10 subthemes through coding and analysis of the interview transcriptions and memos. One core category emerged after the data analysis. The four themes respectively describe the 12 participants' experiences in (a) learning English in their homeland schools, (b) attending different preparation programs, (c) completing university applications, and (d) studying in American universities. After analyzing the four themes, a core category of knowledge 
of English language and U.S. culture was integrated, which is related to all the themes and subthemes.

\section{Theme One: Doubts in Efficiency of English Education at Home}

Ten participants reported that although they had learned English since primary school, English proficiency was the main worry when they recalled their preparation for studying in the United States. Most participants agreed that although they had been learning English in school for years, they found that their English was not communicative at all. They needed to take extra English programs before they took the TOEFL or to study in additional ESL programs before they began their undergraduate studies in the United States. Sungmin, for instance, stated, "Studying English in school in Korea is not really helpful for students to speak and communicate with people who speak English." Shichao in turn said that he started to take afterschool English courses after primary school: "In primary school, I started to [learn] English in a language company in my hometown, to learn from zero." However, when he applied to American universities, his TOEFL score was still too low to be directly admitted.

The statements of the participants are consistent with the literature about the characteristics of schooling in East Asia. Even though most East Asian schools offer English classes beginning in the early grades in primary schools (J. K. Park, 2009; Wang, 2007), learning English under examination-oriented education systems may not allow the students to gain enough English skills for studying in American universities. Over $49 \%$ of the students enrolled in the intensive English programs in 2018 in the United States are from East Asian countries (IIE, 2019). Our findings particularly show that speaking is a neglected skill in English learning in East Asia. Although using a communicative approach in English teaching is advocated by education ministries in most East Asian countries and country areas (Flaitz, 2003; J. K. Park, 2009; Wang, 2007), our participants reported that students seldom practiced speaking in class as speaking was not part of any school test. Thus, when they study at American universities, communicative English becomes one of their biggest barriers.

\section{Theme Two: Efficacy of Study Abroad Preparation Programs}

\section{Testing Preparation Programs}

When asked about how they prepared to study in American universities, nine participants described the strategies they used to take TOEFL and IELTS. Most of them chose to take test preparation courses, regardless of the high course fee. Although they spent much money and time to prepare for the English proficiency tests, not all of them were satisfied with their test scores, especially the speaking section. For instance, Kai stated:

I actually register in the language school. It is a very popular language school in China. I had some probably two or three sessions about TOEFL and just 
general speaking ability exercise there. I also took the TOEFL test, but got a very low score at that point.

Even the participants who achieved decent TOEFL scores through training classes found it hard to adapt to their academic study in the United States. As Nana said, "I think the TOEFL courses I took were very important, because it (sic) helped me have a good score. Otherwise I won't be here. But most I learnt is not useful for my study here."

The findings indicate that East Asian students use various strategies to prepare for the English proficiency tests, but taking test-training programs is the most common strategy among them. The participants report that the test-taking strategies they learn in these programs are more useful than the English language itself. Liu (2014), however, argued that using strategies to take the TOEFL does not significantly affect the scores. In this study, participants found that the strategies became useless for their college studies, but that the strategies were helpful for them to achieve higher scores on the TOEFL.

\section{Other Language Preparation Programs}

When planning to study in American universities, some participants took academic courses or programs taught by native English speakers such as A-level courses, study abroad programs, and college courses and programs taught in English. They found that being taught by English speakers helped them improve their English and better prepare them for their college life in the United States. Shanshan, who studied in an international undergraduate program in China, described her advantages in class compared with other Chinese students who had never studied in Englishmedium programs in China:

Because in my program I studied, the textbook is English, the test is English, the teachers speak in English. And the others, my friends, maybe freshmen here, I have a lot of friends that are freshmen or exchange students. When they study in their cities, they just use the Chinese. So they cannot adapt the English. But I can adapt this [undergraduate courses in the U.S.]. So I think it is good.

When students first come to the United States, however, they find it hard to adapt to their new life, both academically and culturally. For example, Shanshan stated, "Here is different from what I learnt in China. I don't have problem in class, because some class, like Economics, I learnt in China before. But I need help in a lot of things in life."

According to the participants, studying in a study abroad preparation program, taking A-level courses in high school, attending a English-medium college, and participating in an international cooperation program in their homeland may help them better prepare for their college life in the United States. The most useful aspect of these programs is being taught by native English speakers. Consistent with existing research, however, the students still find it difficult to adapt to their new American life at the beginning of their studies (Yan \& Berliner, 2013). 


\section{Preparation Programs in Host Countries}

Our findings indicate that adapting to the English-speaking environment before undergraduate study in English-speaking countries may positively affect academic performance in American universities. In this study, five participants studied in ESL programs in English-speaking countries, and two studied in U.S. high schools before they started their undergraduate study. These participants reported that they felt more academically successful in college than those who had never studied in any Englishmedium programs, or those who had only studied in TOEFL training programs before. Through studying in English-speaking environments, they were more confident in participating in class and talking to native English speakers, compared with other East Asian students who only studied for the TOEFL when they prepared for studying abroad. Dohyun, for instance, stated:

Yeah. I also have a friend whose TOEFL score is 96, but his speaking is not as good as mine. Because he only studied grammar, reading skills, and listening. They can listen whatever they hear, but they cannot speak English as good as me. Speaking is like $90 \%$ in our life. So I think I am better...I am more comfortable in class and I can participate more than they do.

Besides English improvement, participants also emphasized that their experience in English-speaking countries helped them adapt to life in American colleges. Mengchen studied in an American high school for one year, and found it easy to adapt to her college life in the United States:

Well, I think yeah, definitely at the beginning I had [more] advantages than others [international students]... At the beginning people are scared, because they have never been away from their parents and their home, and they are unfamiliar with the rules, how American people talk. Because I lived in America and I have a lot of American friends when I was in high school so I am really comfortable staying here.

However, not all participants were satisfied with their precollege experiences. Kai complained,

It was not as much as I expected from the learning at the ESL program in such a short (period), three months...I wouldn't say it's the least or the worst, but it's just alright. The price is very expensive, but you learn short-term session. They help you improve somehow, but [not very effective]...

\section{Theme Three: Challenges of Completing University Applications}

Due to language barriers and different university application requirements between the United States and their home countries, not all of our study participants could complete their university applications by themselves. Instead, some of them used agency services to complete their applications. In this study, six participants who had relatively higher TOEFL/IELT scores and two participants who had lower TOEFL scores applied to American universities by themselves, while four 
participants who had lower TOEFL scores or did not take TOEFL used an agency help to complete their university and visa applications.

\section{Challenges of Self-Preparation}

Eight participants who applied to universities by themselves described how they completed their applications, which was a challenging process for them. With little assistance from their schools, they mainly searched for all the information online. Some were able to receive help from their teachers from their preparation programs. Kai described, "I think I have asked some questions [for] some professors who had studied in the US." Although applying to U.S. universities is a challenge for East Asian students, it is still possible for them to complete the applications by themselves and successfully receive admission. However, these students' English proficiency is already relatively high, and they often apply for direct admission. In this study, seven of the eight participants who applied to the universities by themselves were directly admitted by their U.S. universities.

\section{Advantages and Disadvantages of Agencies}

The participants using agency services described their agencies as a convenient tool to study abroad. According to Shichao, he did not need to do anything after he paid the agency: "I didn't prepare [by myself]. I used agency. I used agency to do my application. I just followed their suggestion." Dohyun added that using agency services is popular in South Korea. "Actually there is a large group of agencies in South Korea. They are everywhere. I hired them to prepare the application and visa form for me. .... Before I came to the U.S., I knew nothing about here."

However, some participants who not only those applied to universities by themselves, but also used agency help expressed distrust in the study abroad agencies. Pengfei regretted using the agency service, because the agency delayed his enrollment in the ESL program:

The agent company in China I think it's very hmmm... I use the word "bad," because sometimes they only do the things for the basic apply [sic] for the schools. They do not know specific things for the specific student for their need for the specific course. Like why I go to this ESL program is that they just tell you there is a way you can go abroad. I think that is the very big problem in China right now.

Our findings show that it was not easy for East Asian students to complete the university applications all by themselves. For the students who completed their applications by themselves, they received assistance from their teachers, peers, and others. The results also confirmed that agency help was widely used in China and South Korea. Different from Zhang and Hagedorn's (2011) research, which indicated that $70 \%$ of the students who used an agency to apply for universities were satisfied with the service, none of the Chinese participants in our study who used the agency service were fully satisfied with the agency service, and they would not recommend their friends to use agency help. After studying in the United States for a while, they 
realized the agents' knowledge was not more than what they could find online. They recommended that future international applicants complete their applications by themselves.

\section{Theme Four: Academic Success and Challenges in American Universities}

\section{The Importance of High Grades in Universities}

When asked about their understanding of academic success, all the participants narrowly construed academic success as achieving a high grade point average (GPA). Although there are many aspects that represent academic success, most participants in this study defined academic success as simply gaining high grades in school. Originally from countries whose education is test-oriented, the performance score is the core aim of their university study. Most participants stressed the importance of a high GPA to themselves and their parents due to their time and money spent in the United States. Ya-wen identified academic success as "kind of like an achievement." She explained the reason for gaining high scores in college: "Because I spent a lot of money, time, I need to be [a] success."

Academic success was not only important for the participants themselves, but also for their parents. Shanshan for instance indicated, "I think it [academic success] is important, because, as you know, the Chinese family very... They just see your grades. Your graduate GPA, they saw this as the most important thing." She added that if she received a high GPA in school, she would receive rewards from her parents: "It's like scholarship, not scholarship, you know....some goods, or something. Maybe they can give (you) your airplane ticket. You can come back your home. This is... I think is...you know, rewards." According to Rogoff (2003) and C. K. Lee and Morrish (2012), in Confucian culture, academic success was considered as an honor for the whole family. The participants' description of their parental expectations of their academic success reflects this value in Confucian culture.

Furthermore, some participants believed that good academic performance showed their abilities to employers when they applied to jobs. In Sungmin's opinion, "Academic success is important. The most important thing! [A] GPA can say how I study hard in college, and the company I will work in can see [that] this what kind of people [sic] I am." This belief can be widely found in previous research (Choi \& Nieminen, 2013; Mitsui, 2009). Even if they have studied at U.S. universities that do not value high GPA alone as the most important goal of education, they still consider their educational outcomes under East Asian values.

\section{Language Barriers}

When asked about how their English proficiency affected their academic success, most participants agreed that their English proficiency and grades were positively correlated. Shichao, for example, stated, "I think my English skill is related to my GPA, because some class, if your English is not good enough, you just cannot understand the class. It is really important that you have really good English skill." 
Even though they made huge improvements in English during their study abroad preparation and current undergraduate study, English was still the main challenge participants faced in college. Limited writing skills and vocabulary were frequently mentioned by the participants. They perceived that the limitation in writing skills and lack of English vocabulary negatively affected their grades and performance in class. Kai explained that although he wanted to join a brainstorming game in class, lack of vocabulary led him to spend a longer time understanding the game itself then giving answers:

I have telecommunication class which is script writing, and now we have a, play a board game in class to help brainstorm the idea. So in that class we played "Belasco" that really requires you to quickly come out with an idea, description of a role you played a character, what the story development can be, but I feel, sometimes I don't know what to say, because of two reasons. First I don't really understand what is the rule of the game, although I tried my best to read through the description. I still can see some new vocabulary there. Also even though I understand some concept, it takes me a while to say what I think.

In addition, some participants mentioned that slang and idioms in English often confused them. Nana found in daily conversation and in class there were many words that she had never seen in her textbooks. Chin-wah also expressed, "Sometimes in my business class, the professor and my classmates will use some... oh, I think it's slang, slang, and some names of local brands in their examples. I have never heard them before, so that's difficult."

The findings showed that English was essential for them in academic success. The participants perceived that their English proficiency would negatively affect their performance in class. This result is consistent with results of research measuring the relationship between English proficiency and academic performance (Li et al., 2010; Martirosyan et al., 2015). However, most previous studies were only conducted among international students. In this study, when asked about their academic success, all participants compared their performance with American students instead of other international students. This may again reflect East Asian students' high expectations in academic success, which has been widely addressed and found in previous research (Flaitz, 2003; Fong, 2007; H. Park et al., 2011; Rogoff, 2003).

\section{"Still Not Easy": An Outsider on Campus}

Although all the participants reported that they received satisfying grades in class, most of them felt isolated on campus. Our results show that most East Asian students do not learn and understand as much American culture as they expect. In the study, many participants addressed their willingness to join campus activities, but they did not know how to. For instance, Nana stated, “Sometimes you don't get the expected results from the activities. Probably just waste of time, probably just know people to say hello, say nice to meet you, but no longer really anything else happens beyond that." 
When asked about why they felt that they were not involved on campus or in the community, many participants complained that they were not able to learn authentic American culture before they came to the United States and that their university did not offer useful courses or support to help them adapt to American culture. They wished that their universities would offer one course about authentic American culture and American life adaptation. Thus, many East Asian students in American universities may not learn or know how to adapt to a new culture without formal instructions in class.

After studying in the United States, participants found that an efficient way to learn American culture was to make friends with American students. Joowon suggested, "If you want to adapt American culture or if you want to speak English, I will say go out. Don't stay at home. Go to meet your friends. You can only learn English and culture if you speak with others." This finding is consistent with the results in previous research that friendships with host country students help international students adapt to their American lives and increase their life satisfaction in the host countries (Hendrickson et al., 2010; Lin et al., 2011).

In summary, we found that East Asian undergraduate students in American universities start to face difficulties from the time they plan to study abroad, due to the differences in language, schooling, and culture. Knowledge of English and American culture is a core factor affecting East Asian students' academic success in U.S. universities. Although attending preparation programs helped them perform better in college than other international students who had never attended these programs, the challenges in language and cultural adaptation may last through their 4-year undergraduate studies in the United States.

\section{DISCUSSION}

\section{Theoretical Implications}

Knowledge of English language and American culture is a core factor for East Asian students' academic success at American universities. Similar to previous research, our study supports that English proficiency affects international students' academic success (Martirosyan et al., 2015; Oliver et al., 2012). Moreover, this study found that English proficiency also affects East Asian students' choices on study abroad preparation programs, the ways to complete university applications, and their academic success in U.S. universities. All participants in this study with low English proficiencies (IELTS $<6.5$ or TOEFL $<79$ ) chose to use agency services to apply for colleges on their behalves, while students with higher English proficiencies attended various programs to prepare for their studies in the United States and did not use any agency services. After they begin their study in U.S. universities, not only academic English but also the slang and idioms of American English are still barriers for students to understand their professors and American friends, which shows that knowledge of U.S. culture is often ignored by East Asian students until they start their undergraduate study. The participants in this research did not realize their lack of background information in many scenarios on campus until they arrived on campus, which made it hard for them to participate in campus activities with American 
students. Thus, while preparation programs for studying in U.S. universities sometimes helped East Asian student improve their English and performance in college, neglect of learning U.S. culture made them unprepared for adapting to college life in the U.S (Wu et al., 2015). The advantages and disadvantages of study abroad preparation factors are illustrated in Figure 1.

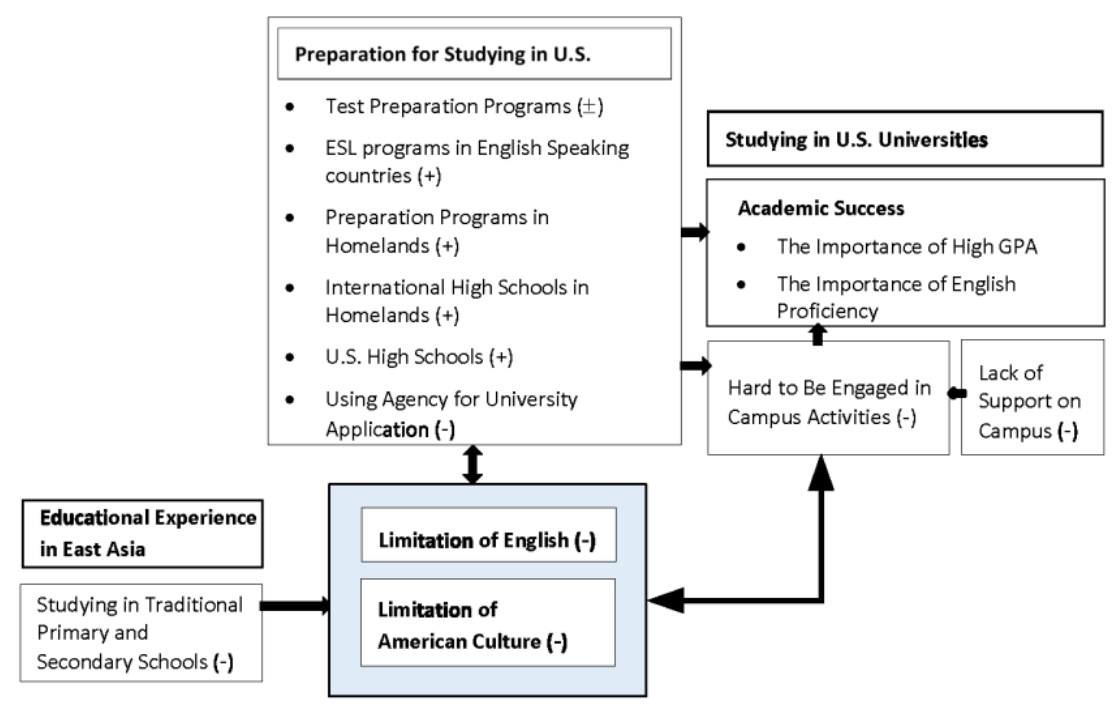

Figure 1: Paradigm of Findings

Note. "+"denotes positive, “-"denotes negative, and “ \pm " denotes both positive and negative influence

Participants' primary through secondary educational experiences in their countries, as well as preparation for studying in the United States, such as taking test preparation classes, studying in international schools, taking intensive English programs, etc., support students' academic success. The more they are engaged in these preparation programs, the better they will adjust academically. The preparation also helps them better understand some academic cultures and campus cultures. However, no matter how much they prepare they still show high anxiety regarding their academic success due to reduced English proficiency and cultural understanding. Thus, English proficiency was highlighted by the participants through all the interviews as the most important factor. It is related to all four themes and 10 subthemes in this study. The students in our study considered English as an essential language tool that affected their academic performance in the United States. Even though their English proficiency has met their respective universities' requirements, they notice that they need more support in English academic writing. Even after studying in American universities for a few years, English is still one of the biggest problems affecting their performance in college. No matter how long and how well 
the participants prepared before they started their undergraduate studies in the United States and how well they performed academically in college, they always felt English to be a barrier they could never overcome and a reason for not obtaining higher academic achievements, and found it hard to be engaged on campus (Bang \& Montgomery, 2013). The challenges certainly might have been different had we studied students from English- speaking countries (either as main language or one of official languages).

Another aspect that was frequently mentioned by our study participants was cultural adaptation. Learning American culture is often neglected when preparing to study in American universities. According to the participants, neither the preparation programs in their homelands nor ESL programs in the United States offered courses related to American culture. Most students do not realize the huge cultural gaps between their home countries and the United States until they start their undergraduate study. Even though most East Asian students are active in learning American culture, they find that there is less support for cultural adaptation for international undergraduate students in American universities, which makes them feel isolated on campus. They often find that they cannot participate in as many campus activities as American students can. They try to take courses that seem related to American culture. However, they find that there is no course or seminar that directly helps them adapt to American culture. Making American friends becomes the most common way for them to learn American culture.

\section{Practical Implications}

The findings of this study enrich knowledge about how East Asian students prepare to study in American universities, the extent to which preparation helps them achieve academic success, and the challenges they face as international students on campus. We suggest that American universities provide more support for cultural adaptation for international students. Besides international student orientation, international students need further support that guides them in learning how to participate in class and being engaged on campus. For example, American universities may help international students establish learning communities or study groups to exchange their knowledge about learning strategies, languages, and cultures. Many universities offer international peer mentoring programs in which trained student mentors help international student mentees adapt to their academic and social life in the United States.

We also suggest that when preparing for study abroad, improving communicative English skills and learning American culture may help students more easily adapt to American university campuses. The results show that East Asian students often spend the most time on English proficiency tests rather than learning the culture when they prepare for studying abroad. They do not realize the importance of knowing American culture until they come to the United States; thus future students should also seek ways to learn American culture during their preparation period. The results also indicate that knowledge of American culture gained before starting undergraduate study helped participants better adapt to college life in United States. Thus, study abroad program developers should consider this and create cultural components 
within their programs. In the same vein, social communities like learning communities would help students to feel more comfortable and confident when interacting with Americans and actively participating in class activities. We noticed that there are many efforts in many universities to help international students to adjust better. For example, in our university, we have programs called "Global Connections" that serve the same purpose. The program organizes a series of cultural activities to connect international students with the local community. Other universities such as the University of Houston and the University of Nebraska-Kearney have international friendship programs. They match an international student with an American family, and the host American families are expected to provide opportunities to help students learn about American cultures, such as taking them on fieldtrips and inviting them over for vacation celebrations. We suggest that other universities could adopt such programs to serve international students better.

\section{Limitations and Further Studies}

There are a few limitations in this study. First, participants from Japan, Mongolia, and North Korea were not recruited due to availability issues, although we consider these countries also to fall within the East Asian region. Likewise, we had more Chinese students because Chinese students represent the highest number of international students in U.S. universities; hence the findings of this study may not be representative of all East Asian students. Second, due to the small sample size in this study, generalizations should be made very cautiously. Third, participants in this study might not have been able to fully express their opinions due to their limited English proficiency. The interviews were conducted in English, and the participants might have found themselves unable to express their thoughts exactly the way they wanted.

Future research investigating the relationship between East Asian students' study abroad preparation and their academic success in American universities on a larger scale would be very helpful and recommended. Increasing the sample size would also help researchers study participants with more diverse experiences. Researchers may for instance investigate and compare how international students from a wider array of different countries prepare for their study in the United States differently. Also, in our study, we collected information regarding the participants' academic major but did not find any responses from the participants wherein they thought their academic majors had any effect on their academic success. This might be due to their academic major playing a role in their perceptions of their own challenges. It might also be because we did not ask specific questions about how their major might have influenced both academic challenges and academic success. Thus, there is room for further study on this topic.

\section{REFERENCES}

Academic Ranking of World Universities (2018). Retrieved April, 5, 2019, from http://www.shanghairanking.com/ 
The agent question: New data has the answer. (2014, September 3). ICEF Monitor. Retrieved from http://monitor.icef.com/2014/09/the-agent-question-new-datahas-the-answer/

Bang, H., \& Montgomery, D. (2013). Understanding international graduate students' acculturation using Q methodology. Journal of College Student Development, $54,343-360$.

Berg, B. L., \& Lune, H. (2004). Qualitative research methods for the social sciences. Pearson.

Bergenfeld, A. M. (2011). Summer Bridge Program at the University of San Francisco for conditionally admitted Chinese students [Unpublished master thesis, University of San Francisco, San Francisco, California]. https://digitalcollections.sit.edu/capstones/2451/

Chan, W. L. (2014). Hong Kong secondary school English teachers' beliefs and their influence on the implementation of task-based language teaching. In English language education and assessment (pp. 17-34). Springer.

Choi, S. H. J., \& Nieminen, T. A. (2013). Factors influencing the higher education of international students from Confucian East Asia. Higher Education Research \& Development, 32(2), 161-173.

Chou, C. P., \& Ho, A.-H. (2007). Schooling in Taiwan. In G. A. Postiglione \& J. Tan (Eds.), Going to school in East Asia (pp. 344-377). Greenwood.

College Board. (2014). Annual AP program participation 1956-2014. Retrieved from http://media.collegeboard.com/digitalServices/pdf/research/2014/ProgSummary-Report-2014.pdfconundrum.html?pagewanted=all\&_r=0

Flaitz, J. (2003). Understanding your international students: An educational, cultural, and linguistic guide. University of Michigan Press.

Fong, V. (2007). Parent-child communication problems and the perceived inadequacies of Chinese only children. Ethos, 35(1), 85-127.

Gong, X., \& Huybers, T. (2015). Chinese students and higher education estimations: Findings from a choice experiment. Australian Journal of Education, 59, 196218.

Hagedorn, L. S., \& Zhang, Y. (2011). The use of agents in recruiting Chinese undergraduates. Journal of Studies in International Education, 15(2), 186-202.

Hendrickson, B., Rosen, D., \& Aune, R. K., (2010). An analysis of friendship networks, social connectedness, homesickness, and satisfaction levels of international students. International Journal of International Relations, 35(3), 281-295.

Hong Kong Education Bureau. (2020). Education system and policy. Retrieved January 28, 2020 from http://www.edb.gov.hk/en/edu-system/list-page.html

Institute of International Education. (2019). Open Doors report on international educational exchange. Retrieved November 18, 2019 from http://www.iie.org/opendoors

Institute of International Education. (2019). Open Doors report on international educational exchange. Retrieved November 18, 2019 from https://www.iie.org/Research-and-Insights/Open-Doors/Data/IntensiveEnglish-Programs/Places-of-Origin 
International Baccalaureate. (n.d.). Find an IB world school. Retrieved from January 28, 2020 https://www.ibo.org/programmes/find-an-ib-school/

James-MacEachern, M., \& Yun, D. (2017). Exploring factors influencing international students' decision to choose a higher education institution: A comparison between Chinese and other students. International Journal of Educational Management, 31(3), 343-363.

Kim, T. (2009). Confucianism, modernities and knowledge: China, South Korea and Japan. In International handbook of comparative education (pp. 857-872). Springer.

Kwon, T., Lee, T., \& Shin, D. (2017) Educational assessment in the Republic of Korea: lights and shadows of high-stake exam-based education system, Assessment in Education: Principles, Policy \& Practice, 24:1, 60-77.

Lee, C. K. C., \& Morrish, S. C. (2012). Cultural values and higher education choices: Chinese families. Australasian Marketing Journal, 20(1), 59-64.

Lee, M., Leung, L., Wright, E., Yue, T., Gan, A., Kong, L., \& Li, J. (2013). A study on the International Baccalaureate Diploma Programme in China: The program influence on students' study in overseas universities. https://www.ibo.org/contentassets/d1 c0accb5b804676ae9e782b78c8bc1c/ibchi nafullreportenglish.pdf

Li, G., Chen, W., \& Duanmu, J-L. (2010). Determinants of international students' academic performance: A comparison between Chinese and other international students. Journal of Studies in International Education, 14, 389-405. https://doi.org/10. 1177/1028315309331490

Lin, J., Peng, W., Kim, M., Kim, S. Y., \& LaRose, R. (2011). Social networking and adjustments among International Students. New Media \& Society, 14(3), 421440.

Liu, O. L. (2014). Investigating the relationship between test preparation and TOEFL iBT performance. ETS Research Report Series, 2014, 1-13. https://doi.org/10.1002/ets2.12016

Martirosyan, N. M., Hwang, E., \& Wanjohi, R. (2015). Impact of English proficiency on academic performance of international students. Journal of International Students, 5, 60-71.

Mazzarol, T., \& Soutar, G. N. (2002). "Push-pull" factors influencing international student destination choice. International Journal of Educational Management, 16(2), 82-90.

Mitsui, N. (2009). Accommodating CLT in Korean EFL classrooms [Unpublished master thesis, Gonzaga University, Spokane, Washington].

Muthanna, A., \& Sang, G. (2015). Undergraduate Chinese students' perspective on Gaokao Examination: Strengths, weaknesses, and implication. International Journal of Research Studies in Education, 5(2), 3-12. Retrieved from http://consortiacademia.org/wp-content/uploads/IJRSE/JJRSE_v5i2/1224-42881-PB.pdf

New Oriental Education and Technology Group. (n.d.). Retrieved from http://www.neworiental.org/english/who/201507/8213540.html 
Nuffic. (2013). Education and diplomas South Korea. https://www.nuffic.nl/en/subjects/education-and-diplomas-south-korea/

Oliver, R., Vanderford, S., \& Grote, E. (2012). Evidence of English language proficiency and academic achievement of Non-English-Speaking background students. Higher Education Research and Development, 31, 541-555.

Pan, L \& Block, D. (2011). English as a "global language" in China: An investigation into learners' and teachers' language beliefs. System. 39 (3). 391-402.

Park, H., Byun, S. Y., \& Kim, K. K. (2011). Parental involvement and students' cognitive outcomes in Korea focusing on private tutoring. Sociology of Education, 84(1), 3-22.

Park, J. K. (2009). "English fever" in South Korea: its history and symptoms. English Today, 25(1), 50-57.

Park, J. S. (2011) The promise of English: Linguistic capital and the neoliberal worker in the South Korean job market. International Journal of Bilingual Education and Bilingualism, 14, 443-455.

Powers, D., \& Rock, D. (1999). Effects of coaching on SAT I: Reasoning test scores. Journal of Educational Measurement, 36(2),93-118.

Ra, Y., \& Trusty, J. (2017). Impact of social support and coping on acculturation and acculturative stress of East Asian international students. Journal of Multicultural Counseling and Development, 45, 276-291. https://doi.org/10.1002/jmcd.12078

Ritchie, J., \& Lewis, J. (2003). Qualitative research practice: A guide for social science students and researchers. Sage.

Roberts, M. (2002). TOEFL preparation: What are our Korean students doing and why? The Korea TESOL Journal, 5(1), 81-106

Rogoff, B. (2003). The cultural nature of human development. Oxford University Press.

Salyers, V., Carston, C. S., Dean, Y., \& London, C. (2015). Exploring the motivations, expectations, and experiences of students who study in global settings. Journal of International Students, 5(4), 368-382.

Shanghai Ranking Consultancy. (2014). Academic ranking of world universities. Retrieved from http://www.shanghairanking.com/ARWU2014.html

Starr, D. (2012). China and the Confucian education model. (A position paper). Universitas 21. 1-26. https://www.abebooks.com/9780957006614/ChinaConfucian-Education-Model-Don-0957006616/plp

Suen, H. K., \& Yu, L. (2006). Chronic consequences of high-stakes testing? Lessons from the Chinese civil service exam. Comparative Education Review, 50(1), 4665.

Wang, Q. (2007). The national curriculum changes and their effect on English language teaching in the People's Republic of China. In J. Cummins \& C. Davison (Eds.), International handbook of English language teaching: Part one (pp. 87-105). Springer.

Winn, P. (2012, January, 4). Elite Asian students cheat like mad on US college applications.

http://www.globalpost.com/dispatch/news/regions/asia-

pacific/thailand/120103/US-college-application-fraud-asia-elite-economy-china 
Wu, H., Garza, E., \& Guzman, N. (2015). International student's challenge and adjustment to college. Education Research International, 2015, Article 202753.

Xie, H. (2011). Zhong guo jiao yu tong ji nian jian [Educational statistics yearbook of China]. People's Education Press.

Yan, K., \& Berliner, D. C. (2013). Chinese international students' personal and sociocultural stressors in the United States. Journal of College Student Development, 54(1), 62-84.

Zhang, Y., \& Hagedorn, L. S. (2011). College application with or without assistance of an Education agent: Experience of international Chinese undergraduates in the US. Journal of College Admission, 212, 7-16.

MEIREN CHEN, MA, is the International Partnerships Coordinator at University of Northern Colorado. She received her undergraduate degree in English from Communication University of China and her master's degree in cross-cultural and international education from Bowling Green State University. Previously she worked in positions in study abroad advising in China and international admissions and recruitment in the United States. Her research interests include college admissions, college experiences and outcomes among international students, and cross-cultural adaptation. Email:meiren.chen@unco.edu

HYEYOUNG BANG, $\mathrm{PhD}$, is an Associate Professor, and teaches educational psychology, human growth and development, and cross-cultural human development in the School of Educational Foundations, Leadership, and Policy at Bowling Green State University. She utilizes quantitative, qualitative, mixed methods, and Q methodology in her research. Her research agenda includes wisdom in the development of self; morality, virtue, and contemplation in life; acculturation, resilience, and motivation, and schooling international and minority students in the US. Email: hbang@bgsu.edu 